\title{
EFFECTIVENESS OF GEOTEXTILE TUBE AS A BREAKWATER CORE
}

\author{
Hendra Hidayat $^{1}$ and Steven Andrianto ${ }^{2}$
}

Geotextile Tube is an innovative technology which can be used as the core of a breakwater structure to address shoreline erosion problems. One of the advantages of Geotextile Tubes is the use of sand fill material which is available in most project sites. Another significant advantage of Geotextile Tube system is simple and fast in installation When a filled Geotextile Tube is combined with rocks and concrete armour units, Geotextile Tube Breakwaters become an effective structure in absorbing wave energy thus preventing shoreline abrasion.

Keywords: rubble-mound breakwater;Breakwater Core; Geotextile Tube; Woven Geotextile; Settlement

\section{INTRODUCTION}

The breakwater is an essential structure required prior to commencement of land reclamation work. "K Island", is one of the 17 islands that will be created as part of the "Jakarta Water Front City Development Project" in Ancol, North Jakarta. The reclamation area is about 35 hectares. K island reclamation is planned to be part of an amusement park development of the Fantasy World theme park.

The breakwater (which in this project is also part of the containment dyke structure) is very important because of its function as a retaining structure and as protection of reclamation area against abrasion from sea-wave. The challenges of this project are: seabed consists of a thick soft soil layer (hence the bearing capacity is very low); sea waves; sea currents; and extreme tidal conditions. To meet with these challenges, geotextile tube was selected to serve as a containment dyke, as well as forming the core of the breakwater with A-Jack concrete blocks as the armour layer.

This Paper will discuss the effectiveness of geotextile tube application as the core of the breakwater in Reclamation of ' $\mathrm{K}$ ' island, North of Jakarta, Indonesia.

\section{GEOTEXTILE TUBE}

Geotextile tubes are long, sausage-shaped containment units that are formed in-situ on land or in water, (Fig. 1). They are filled by hydraulically pumping sand-fill into the tubes and range in size from $1 \mathrm{~m}$ to $6 \mathrm{~m}$ in diameter, and up to $100 \mathrm{~m}$ in length.

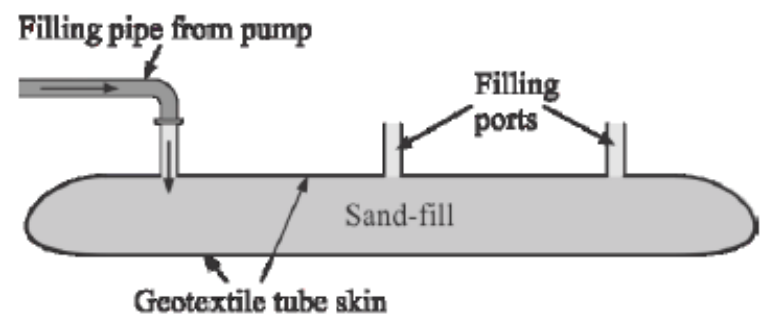

Figure 1. Geotextile tube long section detail

Geotextile tubes are used for a range of riverbank and coastal protection applications requiring mass gravity protection units. These applications are shown in Fig. 2, and described briefly below.

\footnotetext{
${ }^{1}$ PT. Geotechnical Systemindo, Jakarta, Indonesia hendra@ptgsi.com

2 PT. Geotechnical Systemindo, Jakarta, Indonesia steven@ptgsi.com
} 


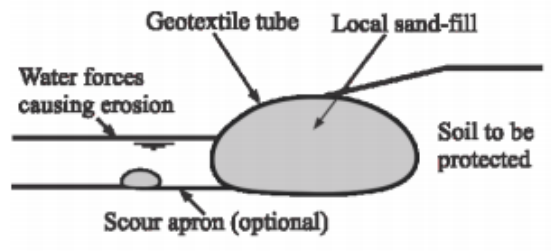

a) Revetments - exposed and submerged

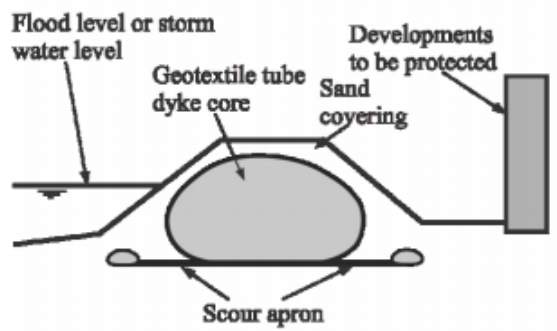

c) Protection dykes

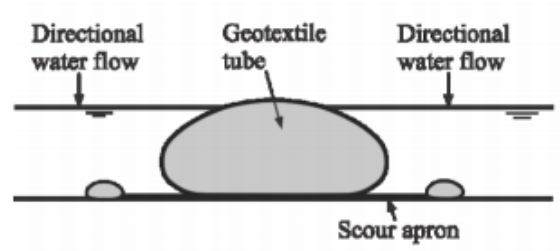

e) Training walls

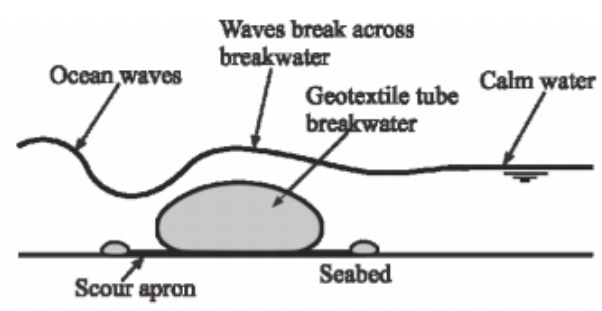

b) Offshore breakwaters

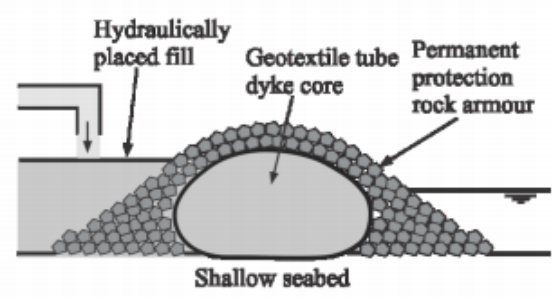

d) Containment dykes

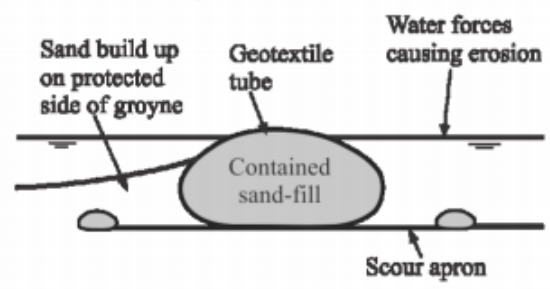

f) Groynes

Figure 2. Application of Geotextile Tubes

Geotextile material used for geotextile tube must have a high tensile strength to receive high pumping pressure during tube filling process. In addition, the geotextile material also should have a suitable apparent opening size to retain sand fill material from flowing out during and after sand pumping.

Although Geotextile tube material is resistant to UV rays, long term exposure to UV rays will degrade its Tensile Strength so it is necessary to apply additional UV protection layer such as a nonwoven geotextile.

According to GRI GT11 Test Method: Standard Practice for Installation of Geotextile Tubes used as Coastal and Riverine structure, a geotextile tube is a large tube (with a circumference of more than 2.3 $\mathrm{m}$ ) is made from high strength, woven geotextile with a length of more than 6.1 meters,

The advantages of the geotextile tube:

- No significant environmental impact

- Strong and durable

- Effective retaining wall

- Strong breakwater structure

- Practical and easy in application

- Fill material can be taken from the local area

- Efficient and effective

\section{USE OF GEOTEXTILE TUBE ON BREAKWATER DESIGN}

In general, a breakwater consists of two components, namely core and armour (Fig. 3). The core of a breakwater can be composed of rock material or sand. When sand is used as the core material of a breakwater, it needs to be placed into a container. The core is protected by armour, in this case using concrete armour units named 'A-Jack'. In coastal engineering, an A-Jack consist of two concrete Tshaped pieces joined perpendicularly at the middle, forming six legs. A-Jack shape is designed to dissipate the force of incoming waves by allowing water to flow through rather than against it and to reduce displacement by allowing a distribution of A-Jack to form a strong interlocking. At the bottom of 
a breakwater, geotextile mattresses is placed to provide an uniform load distribution caused by loads of the Geotextile Tubes.

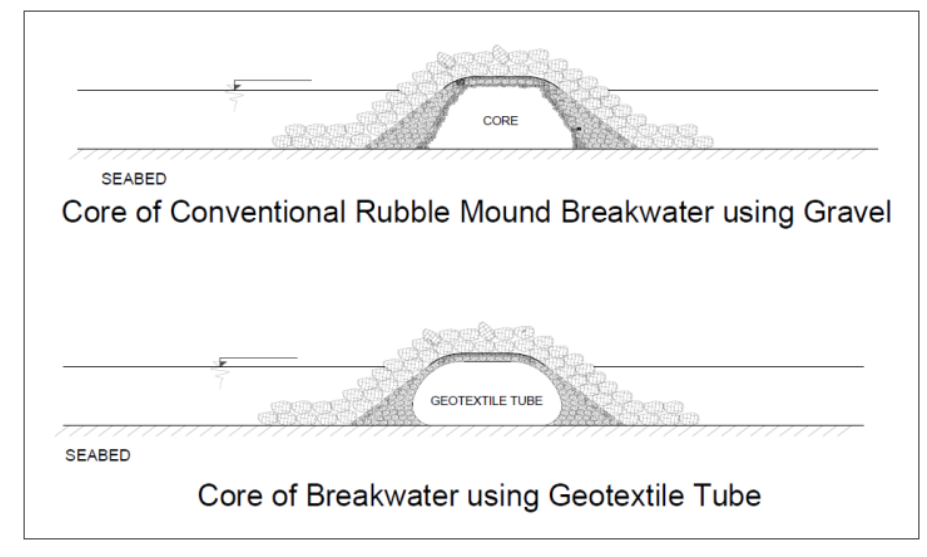

Figure 3. Core of Breakwater using Geotextile Tube

\section{Breakwater Design}

From the historical tidal data range taken between 1978 to 2006, the following tidal design parameters were determined 1.29 m HHWL, 0.6 m MSL, and 0 m LLWL (Table 1).

Table 1. Tidal Data vicinity of Ancol, Jakarta

\begin{tabular}{|l|l|l|l|l|l|l|}
\hline \multicolumn{1}{|c|}{ Water Tide Level } & 1978 & 1979 & 1990 & 2001 & 2006 & Design \\
\hline Highest High Water Level (HHWL) & 1.29 & 1.29 & 1.26 & 1.10 & 1.19 & 1.29 \\
\hline Mean Sea Level (MSL) & 0.60 & 0.60 & 0.60 & 0.54 & 0.62 & 0.60 \\
\hline Lowest Low Water Level (LLWL) & 0.00 & 0.00 & 0.00 & 0.00 & 0.00 & 0.00 \\
\hline
\end{tabular}

Wave parameter must be considered in the breakwater design process which can be generated from hourly wind data that interact with the water surface and generating waves in evoked area called fetch.

Table 2. Wave Parameters

Table 2. Wave Parameters
\begin{tabular}{|c|c|c|}
\hline $\begin{array}{c}\text { Return } \\
\text { Period }\end{array}$ & $\begin{array}{c}\text { Waves } \\
\text { Height }\end{array}$ & $\begin{array}{c}\text { Waves } \\
\text { Period }\end{array}$ \\
\hline (Years) & (Meters) & (Seconds) \\
\hline 1 & 2.20 & 7.11 \\
\hline 2 & 2.41 & 7.47 \\
\hline 3 & 2.62 & 7.82 \\
\hline 5 & 2.86 & 8.20 \\
\hline 10 & 3.16 & 8.66 \\
\hline 25 & 3.53 & 9.20 \\
\hline 50 & 3.81 & 9.59 \\
\hline 100 & 4.00 & 9.96 \\
\hline
\end{tabular}

Based on the local situation, (Table 2) and future development, 10 years return period was taken into design parameters with the dominant wave come from north direction.

\section{Height of breakwater}

A breakwater must have a sufficient height in order to reduce the wave energy optimally. The height must consider water level, wave height, and run-up height caused by wave propagation.

\section{Iribarren number}

The Irribaren number is a dimensionless parameter used to model several effects of (breaking) surface gravity waves on beaches and coastal structures. It can be calculated and predicted how high the run-up will be when the design wave height is applied to the structure. 


$$
I r=\frac{\tan \theta}{\sqrt{\frac{H}{L_{0}}}}
$$

With $L_{0}$ is the deep-water wavelength

which :

$$
L_{0}=\frac{g T^{2}}{2 \pi}
$$

$$
\begin{array}{ll}
\text { Ir } & : \text { Iribarren number } \\
\tan \theta & : \text { Slope of Breakwater } \\
H & : \text { Wave Height } \\
g & : \text { gravity } \\
T & : \text { Wave Period }
\end{array}
$$

the height of run-up can be predicted by considering the ratio between wave height and the iribarren number. The minimum breakwater height to accommodate dynamic water level can be calculated based on tidal range, wave height, and run-up.

\section{Weight of concrete armour}

The weight of armour must be calculated in the design process to ensure the protecting armour has a good stability against wave force. Armour weight can be calculated by using Hudson formula.

$$
w=\frac{\gamma_{\text {armor }} H^{3}}{K_{D}\left(\frac{\gamma_{\text {armor }}}{\gamma_{\text {water }}}-1\right)^{3} \cot \theta}
$$

which :

$$
\begin{array}{ll}
w & : \text { Weight of concrete armour } \\
\gamma_{\text {armor }} & : \text { Armour Density } \\
K_{D} & : \text { Stability Coefficient } \\
\gamma_{\text {water }} & : \text { Sea Water Density } \\
H & : \text { Wave Height } \\
\cot \theta & : \text { Slope of breakwater }
\end{array}
$$

\section{Crest width}

The crest width is determined by allowable overtopping condition. In the allowed overtopping condition, the minimum crest width is about the width of 3 armour units. Crest width shall be wide enough to accommodate operation and maintenance access.

Crest width can be calculated by using this formula,

With :

$$
B=\eta K_{\Delta}\left(\frac{w}{\gamma_{\text {armor }}}\right)^{\frac{1}{3}}
$$

$$
\begin{array}{ll}
B & : \text { Crest Width } \\
\eta & : \text { Unit Armour } \\
K_{\Delta} & : \text { Layer Coefficient } \\
w & : \text { Armour Weight } \\
\gamma_{\text {armor }} & : \text { Armour Density }
\end{array}
$$

By using the formula above, minimum width of the breakwater crest can be calculated.

Figures 4 and 5 below shows the general layout and cross section of the breakwater built at ' $\mathrm{K}$ ' island, North of Jakarta, Indonesia. 


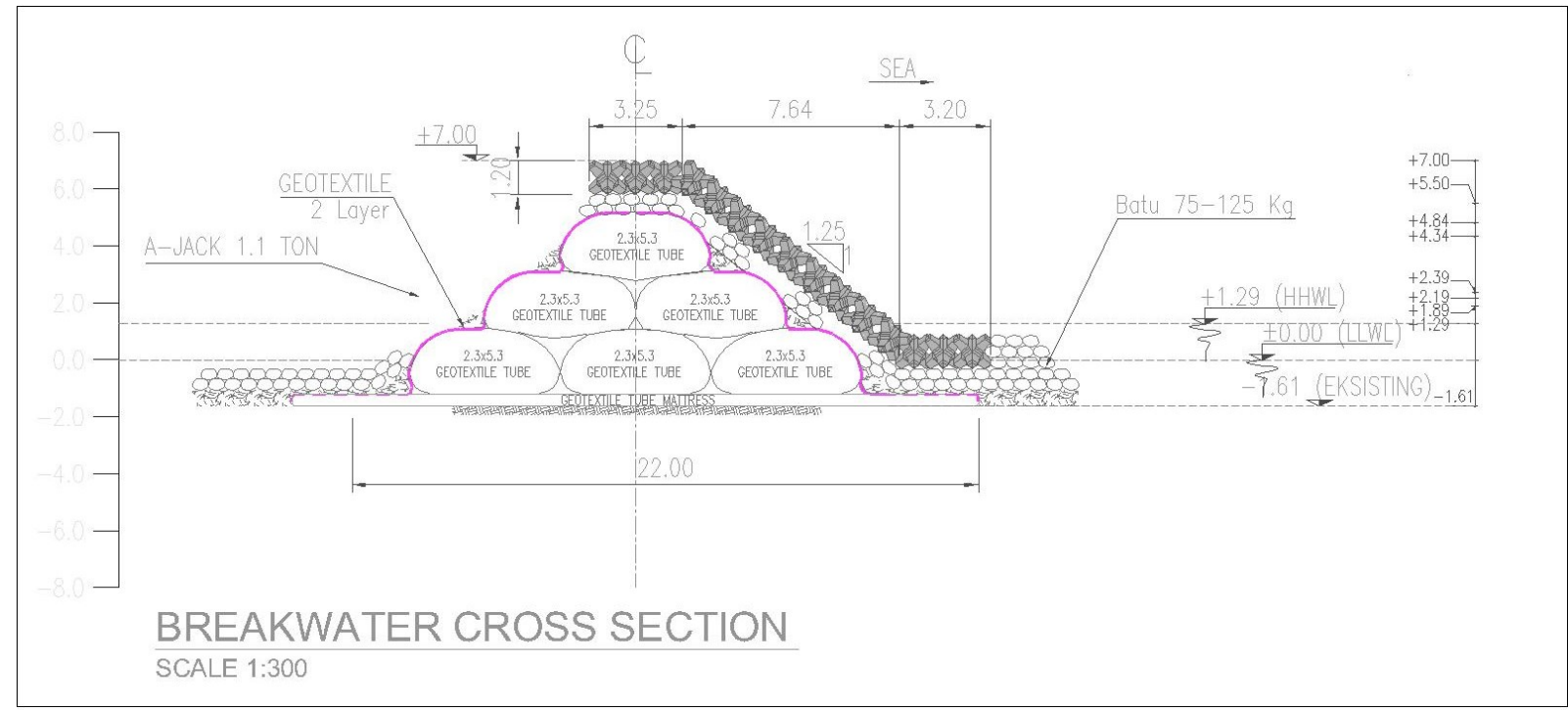

Figure 4. K-Island Breakwater Cross Section

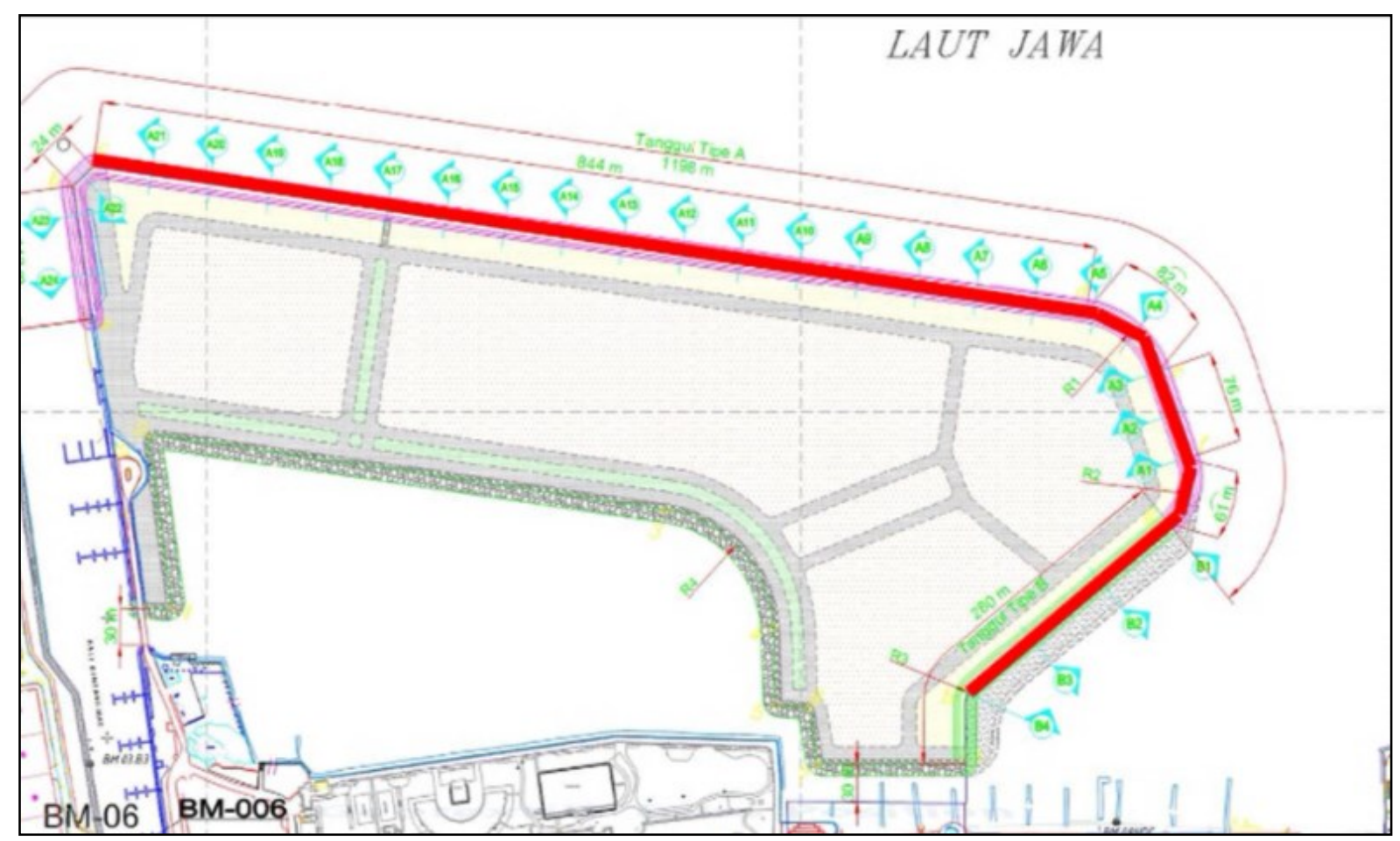

Figure 5. K Island Project Layout

\section{Geotextile Tube as core of breakwater}

In order to determine a suitable dimension and strength of geotextile tube material, properties of sand, height/ width of core dimension and water level are required (Fig. 6) 


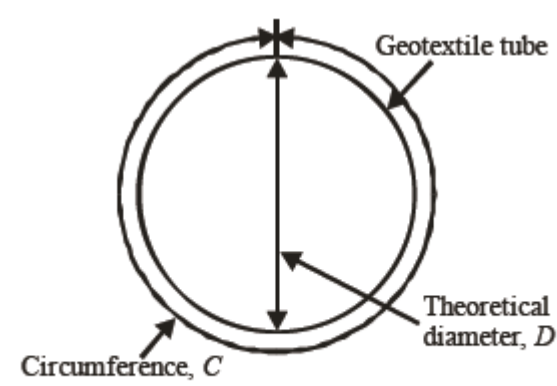

a) Fundamental geotextile tube parameters

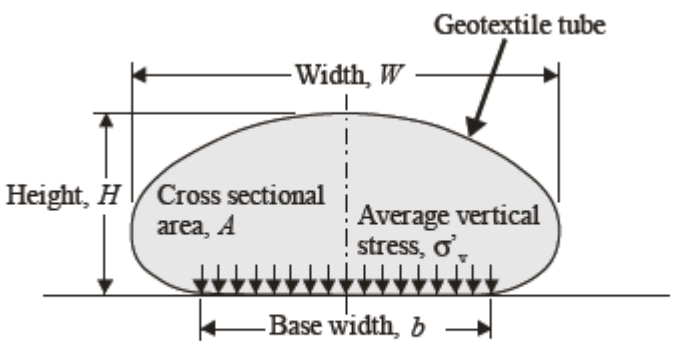

b) Engineering parameters of importance for filled geotextile tubes

Figure 6. Illustration of the parameter needed in designing Geotextile Tube

The dimensions and properties of geotextile material are determined by using computer software called GeoCops (Geosynthetic Confined Pressurized Slurry).

From a technical standpoint, geotextile tubes must meet the following requirements (Fig. 7) (Yee, 2002): Internal Stability

- The geotextile material used to fabricate the tube, including seams and closure need to withstand the stresses that may be encountered during the placement and filling process.

- The geotextile tubes should prevent excessive loss of fines, but be sufficiently permeable to prevent excessive buildup of pressures during installation.

External Stability

- The geotextile tube should be hydraulically stable against waves and currents

- The geotextile tube should be geotechnically stable against sliding, bearing, overturning and Durability global slip failures.

- The geotextile should endure and perform the engineering functions over the lifespan of the design. 


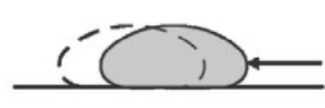

(i) Sliding stability

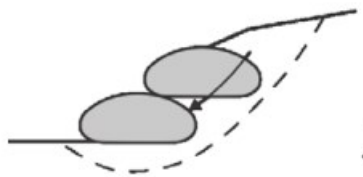

(iv) Global stability

a) External stability

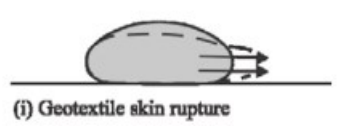

b) Internal stability

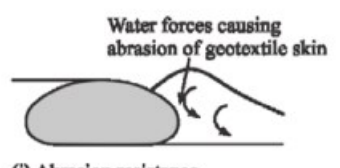

(i) Abrasion resistance

c) Durability

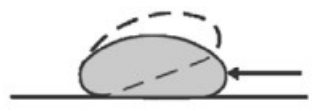

(ii) Overturning stability

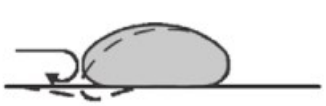

(v) Foundation scour

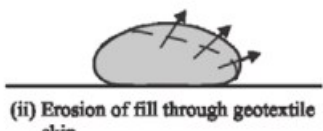

skin

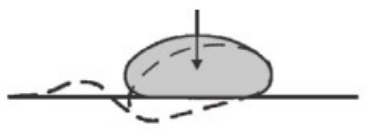

(iii) Bearing stability

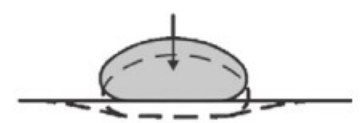

(vi) Foundation settlement
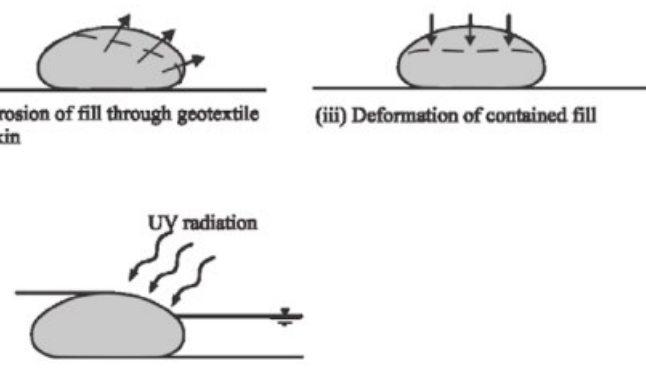

(ii) UV resistance

Figure 7. Design Limit Modes for Geotextile Tube

Geotextile material used for geotextile tube must have a high tensile strength able to withstand loads during tube filling process. In addition, this material also should have optimum opening size and permeability.

Geotextile tube material is not fully resistant to UV rays, so it is necessary to apply an additional layer of non-woven geotextile to act as an UV protection as well as a puncture protection layer from sharped objects such as rocks/armour units which are placed on the Geotextile Tubes.

Sand used to fill the geotextile tube should have a grain size of at least $0.35 \mathrm{~mm}$ with a medium or coarse qualification. Tolerance for fine particles below $0.35 \mathrm{~mm}$ is limited up to $8 \%$.

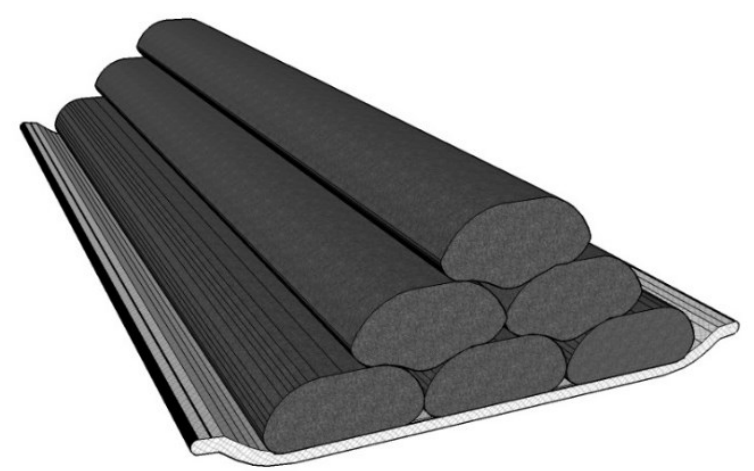

Figure 8. Geotextile Tube as a core of Breakwater

Specifications of the geotextile tube for ' $\mathrm{K}$ ' island is as follows:

$\begin{array}{ll}\text { MD tensile strength } & : \geq 200 \mathrm{kN} / \mathrm{m} \\ \text { Strong Pull CD } & : \geq 200 \mathrm{kN} / \mathrm{m} \\ \text { Static puncture CBR } & : \geq 23000 \mathrm{~N} \\ \text { Aperture size } & : \leq 0.297 \mathrm{~mm} \\ \text { Filled Height (H) } & : 2.3 \mathrm{~m}-2.4 \mathrm{~m} \\ \text { Circumference } & : 12.5 \mathrm{~m}-12.9 \mathrm{~m} \\ \text { Filled Width (W) } & : 5.2 \mathrm{~m}-5.3 \mathrm{~m}\end{array}$


Specifications of non-woven geotextile protection layer is as follows:

Rod puncture CBR : $15500 \mathrm{~N}$

Tensile strength at break : $95 \mathrm{kN} / \mathrm{m}$

\section{The armour}

A-Jack Armour is installed at outermost part of the breakwater to reduce wave energy (Fig. 9).
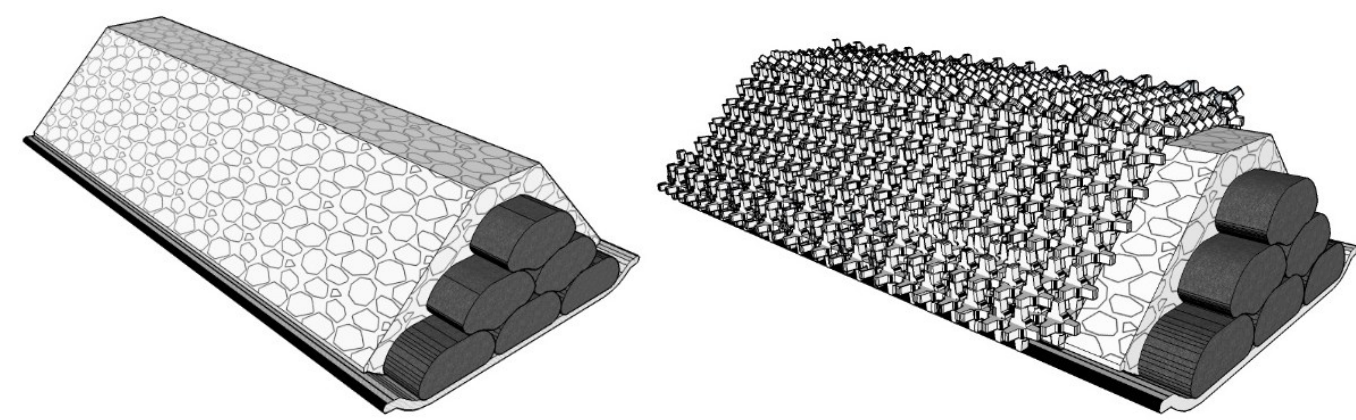

Figure 9. Breakwater with Armour

\section{Settlement of Geotextile Tube}

The seabed consists of very soft clay with 10 meters of thickness. This became one of the challenges to construct the breakwater structure. Geotextile tube was selected as the core of the breakwater structure because of its flexibility to adapt to soil surface conditions. Since the base soil are very soft, the consolidation settlement need to be considered. To prevent differential settlement, geotextile mattresses are placed below geotextile tube system. The mattresses acts as a base that distribute the load evenly to the seabed. Since the load is distributed evenly, it prevents differential settlement and reduce soil consolidation settlement.

\section{Geotextile mattress}

Geotextile mattresses consist of two connected layers of geotextile where the space between is filled with sand. The resulting mattress shape is composed of sand-filled tubular compartments that maintains their mass-gravity and prevents movement of the sand-fill within the mattress, (Fig. 10). The prefabricated geotextile mattress is hydraulically filled with sand.

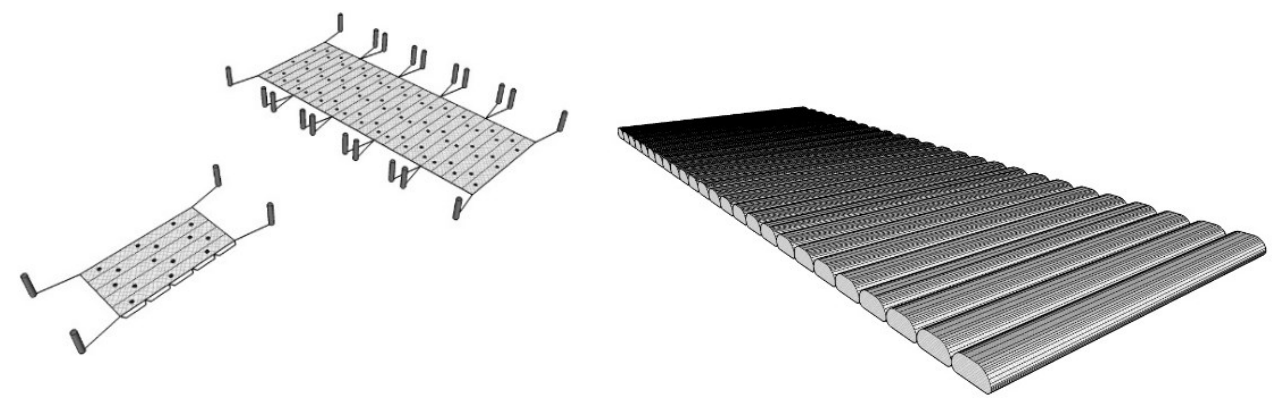

Figure 10. Geotextile mattresses

Specification of the geotextile mattresses for ' $\mathrm{K}$ ' island is as follows:

$\begin{array}{ll}\text { Tensile strength MD } & : \geq 50 \mathrm{kN} / \mathrm{m} \\ \text { Tensile strength CD } & : \geq 50 \mathrm{kN} / \mathrm{m} \\ \text { Static puncture CBR } & : \geq 4500 \mathrm{~N} \\ \text { Aperture size } & : \leq 0.354 \mathrm{~mm} \\ \text { Length } & : 20 \mathrm{~m} \\ \text { Width } & : 7.2 \mathrm{~m} \\ \text { Filled Height } & : 0.3 \sim 0.4 \mathrm{~m}\end{array}$


Settlement Calculation

For $\mathrm{U} \leq 60 \%$ :

$$
C_{v}=\frac{T v \cdot H^{2}}{t}
$$

For $\mathrm{U}>60 \%$ :

$$
T_{v}=\frac{\pi}{4}\left(\frac{U \%}{100}\right)^{2}
$$

$$
\mathrm{TV}=1,781-0,933 \log (100-\mathrm{U} \%)
$$

$\mathrm{Cv} \quad$ : consolidation coefficient $\left(\mathrm{cm}^{2} / \mathrm{s}\right)$

Tv : time factor from the consolidation degree

$\mathrm{t} \quad$ : time $\mathrm{U} \%(\mathrm{~s})$

$\mathrm{H} \quad$ : soil height $(\mathrm{cm})$

Based on the consolidation settlement calculation using Terzaghi theory, the predicted total consolidation settlement was $3.2 \mathrm{~m}$ within 3.4 years. By using geotextile mattresses which is placed underneath of the geotextile tube, the settlement can be reduced to $2.6 \mathrm{~m}( \pm 19 \%)($ Fig 11$)$.

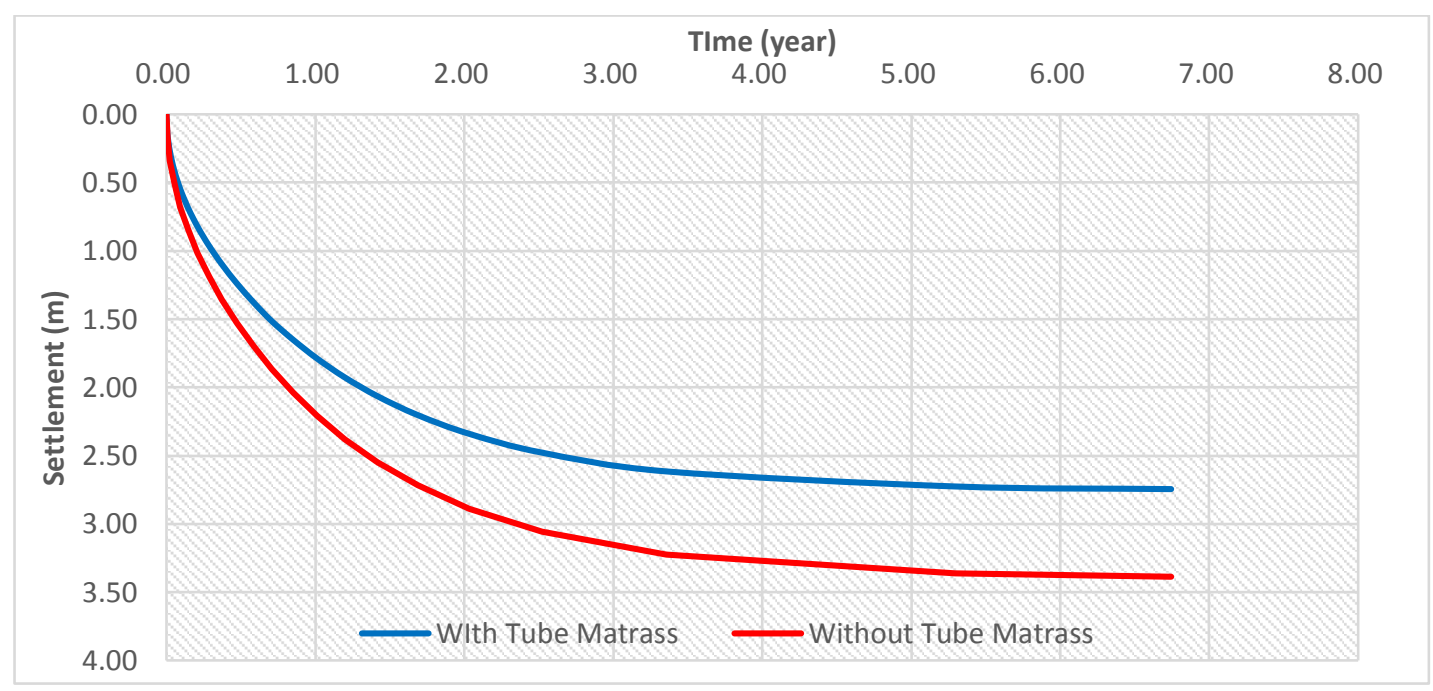

Figure 11. Settlement Comparison with and without geotextile (tube) mattress

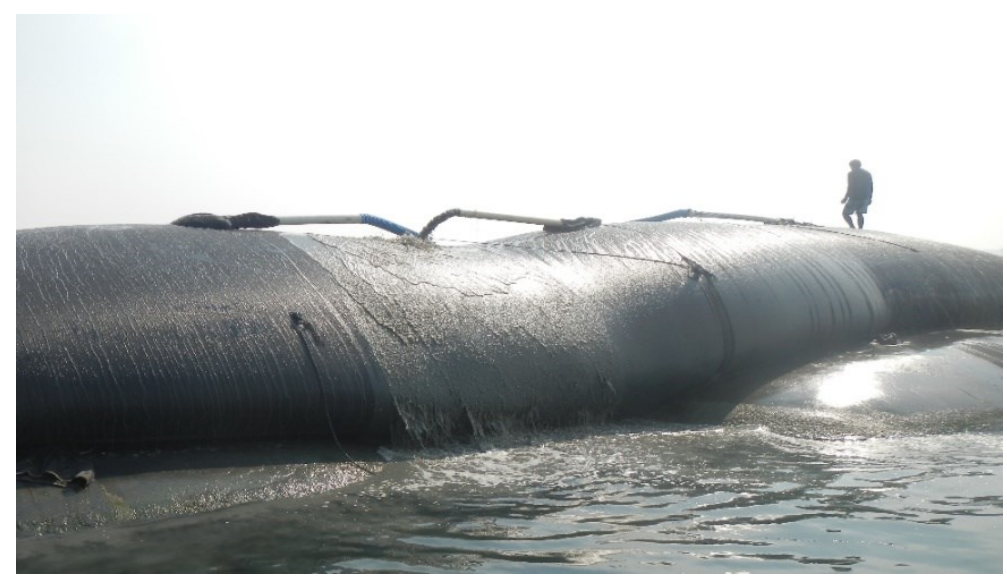

Figure 12. Installation of Geotextile Tube as a core of Breakwater 


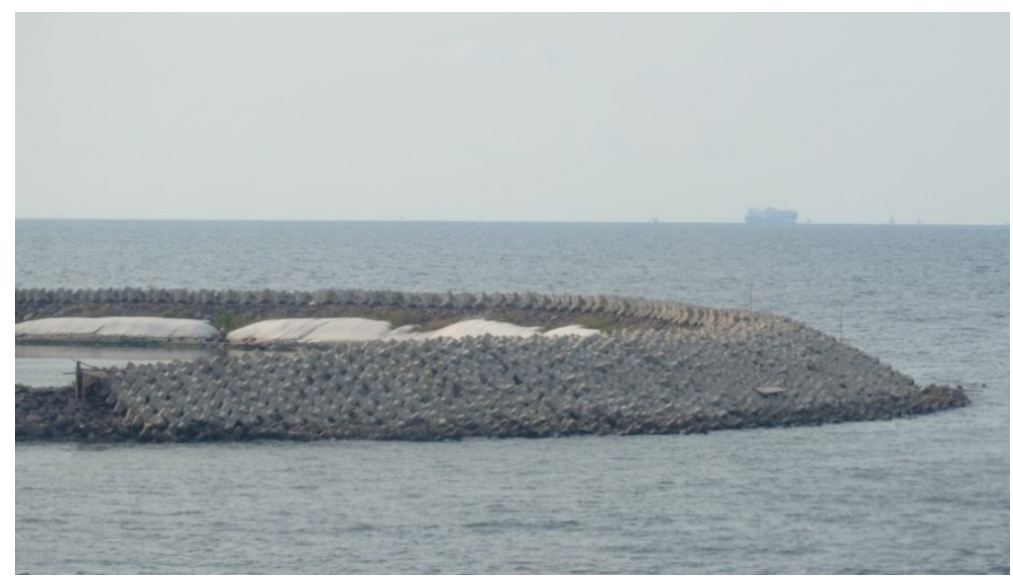

Figure 13. Breakwater with Geotextile Tube as a core

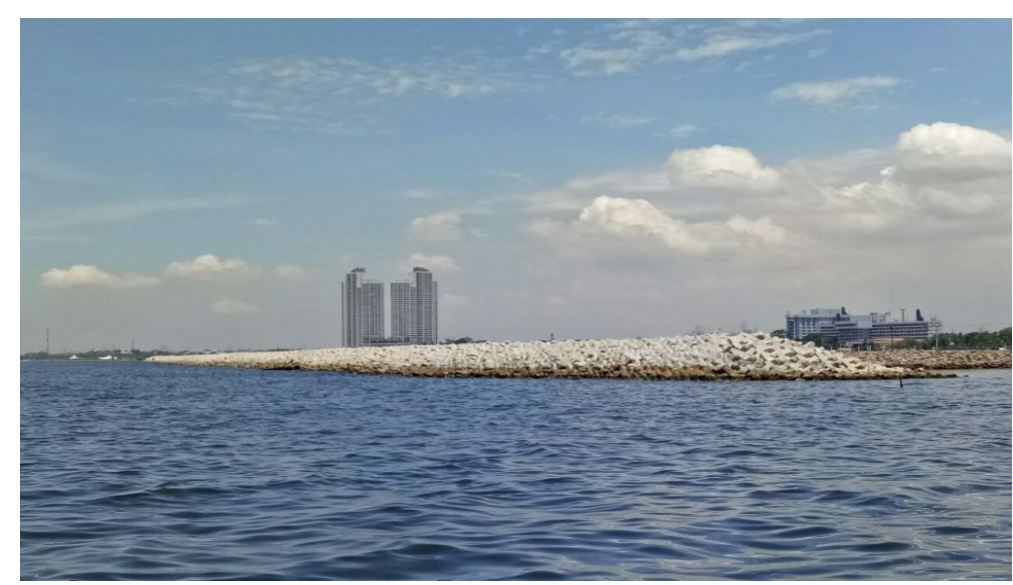

Figure 14. Breakwater with Geotextile Tube as a core

\section{CONCLUSION}

Geotextile tube can be used as an alternative solution for the core of a breakwater because of its strength and durability. It is a cost effective solutions compared to a conventional rubble mound breakwater. In addition, use of geotextile mattresses prevents excessive settlement especially on a very soft seabed condition.

Specification of geotextile tube fabric and filler material are the main factors to be considered in designing a geotextile tube. A High Strength Woven geotextile is a must in the fabrication of large dimension geotextile tubes.

\section{REFERENCES}

GRI Test Method GT11. 2012. Standard practice for "Installation of Geotextile Tube used a Coastal and Riverine Structure", Geosynthetics Institute.

Yee, T.W. 2002. Construction of Underwater Dykes Using Geotextile Containment Systems, Proceedings of the Seventh International Conference on Geosynthetic, Nice, France, 3, 11611164.

Lawson, C.R. 2006. Geotextile Containment for Hydraulic and Environmental Engineering, Proceedings of 8th Geosynthetics International Conference, Millpress, Rotterdam. 9-48

Shore Protection Manual 1984 volume 2 Department of the Army Waterways Experiment Station, Corps of Engineer, Coastal Engineering Research Center, 6, 93-98, 7, 16-32, 7,202-249.

Kinog.K , Tuah.H, Wurjanto.A, Idris.K. (2005) Journal "Kestabilan Armour pada Breakwater Tenggelam" Vol 12 No.1 2005, 1-12.

Triatmojo. B. 2010. Perencanaan pelabuhan. Beta Offset, Yogyakarta 159-188. 